\title{
Edukasi Budi Daya Ikan Lele Kolam Terpal di Panti Asuhan Nurul Ikhsan Merawang Kabupaten Bangka
}

\section{(Education of Catfish Terpaulin Pond at Nurul Ihsan Orphanage Merawang Bangka District)}

\author{
Fika Dewi Pratiwi ${ }^{*}$, Eddy Jajang Jaya Atmadja ${ }^{2}$, Rufti Puji Astuti ${ }^{2}$ \\ 1 Program Studi Manajemen Sumberdaya Perairan, Fakultas Pertanian, Perikanan dan Biologi, Universitas Bangka Belitung, \\ Jln. Kampus Terpadu, Balunijuk, Bangka, Provinsi Kepulauan Bangka Belitung 33172. \\ 2 Program Studi Agribisnis, Fakultas Pertanian, Perikanan dan Biologi, Universitas Bangka Belitung Jln. Kampus Terpadu \\ Balunijuk, Bangka, Provinsi Kepulauan Bangka Belitung 33172. \\ *Penulis Korespondensi: fikapratiwi.12@gmail.com \\ Diterima Desember 2019/Disetujui Oktober 2020
}

\begin{abstract}
ABSTRAK
Ikan lele dapat dibudidayakan dengan waktu relatif singkat 2-3 bulan, serta menguntungkan bagi yang membudidayakannya. Tingginya permintaan konsumen ikan lele membuka peluang kepada setiap orang untuk dapat melakukan usaha budi daya, tidak terkecuali santri panti asuhan. Tujuan kegiatan pengabdian ini adalah untuk mengedukasi santri mengenai cara budi daya ikan lele pada kolam terpal dengan menerapkan teknologi probio_Fm (bahan probiotik yang dapat meningkatkan kualitas air budi daya). Kegiatan berlangsung pada bulan November-Desember 2018, lokasi di panti asuhan Nurul Ikhsan, Desa Batu Rusa, Kecamatan Merawang, Kabupaten Bangka, Provinsi Kepulauan Bangka Belitung. Pesertanya 40 orang santri laki-laki dan perempuan. Tahapan kegiatan meliputi: 1) Persiapan (koordinasi, survei lokasi, dan persiapan alat serta bahan); 2) Pemberian materi budi daya lele dengan metode ceramah dan diskusi; 3) Pendampingan (pembuatan kolam terpal dan manajemen kualitas air kolam dengan probio_Fm); 4) Monitoring dan evaluasi (pembagian kuesioner). Berdasarkan kuesioner, rata-rata lebih dari 50\% peserta menyatakan bahwa mereka setuju jika dikatakan termotivasi untuk mengikuti kegiatan pengabdian, materi dan praktik mudah dipahami dan sesuai dengan kebutuhan, metode dan sarana pengabdian sudah tepat, selain itu mereka menyatakan setuju untuk diadakan kegiatan lanjutan dari program yang telah diselenggarakan. Kegiatan pemberdayaan telah berhasil mengedukasi santri mengenai budidayakan ikan lele dalam kolam, namun pemeliharaan ikan lele sampai dengan panen perlu pendampingan secara intensif bagi santri karena merupakan pemula. Edukasi analisis usaha budi daya bisa dilakukan untuk lebih memotivasi santri melakukan usaha budidaya lele.
\end{abstract}

Kata kunci: ikan konsumsi, konvensional, pemberdayaan, probio_Fm

\begin{abstract}
Growing catfish is relative needs a short time (3-4 months) that can be profitable for cultivators. The increase of public demand for catfish provides an opportunity for everyone to carry out this business, including the orphanage students. Because of this, the orphan empowerment aimed to educate and practice the basics of conventional catfish farming used probio-Fm technology. The program was conducted in November-December 2018. The empowerment program location was at Nurul Ikhsan Orphanage, Batu Rusa village, Merawang District, Bangka Regency, Bangka Belitung Islands Province. The participants were 40 orphans. Four steps of the program consisted of 1) preparation (coordination, survey, and materials preparation), 2) discussion of the training materials (management of conventional catfish farming) 3) Field practice (demonstration of plastic fish tank design and application of probio-Fm) 4) Monitoring and evaluation (the distribution of the questionnaire). Based on the questionnaire, the average of participants $(50 \%)$ agreed if they categorized as motivated participants in the program, the Transfering theory and practice methods were easy to understand and follow their needs. Besides, they agreed on the continuity of the program. We concluded that the program succeeded in educating the orphan student about cultivating the catfish with the conventional method based on probio-Fm, however, catfish maintenance should be accompanied by the intensive assistance until harvest. Educating catfish business analysis could more motivate the orphanage student to practice catfish farming.
\end{abstract}

Keywords: consumption fish, conventional, empowerment, probio_Fm 


\section{PENDAHULUAN}

Budi daya ikan merupakan upaya yang dapat dilakukan masyarakat dalam rangka menyediakan sumber protein hewani, selain itu usaha budi daya secara tidak langsung membantu menyukseskan program pembangunan di bidang perikanan (Saparinto 2013). Budi daya ikan dapat dikontrol dalam kondisi yang relatif tidak terlalu dipengaruhi oleh musim dan cuaca (Wardiningsih 2014). Jenis ikan air tawar yang banyak dibudidayakan salah satunya adalah ikan lele. Peluang budi daya ikan lele sangat terbuka untuk dikembangkan karena tingginya permintaan konsumen di berbagai wilayah di Indonesia (Triyanti \& Shafitri 2012). Oleh karena itu, ikan lele merupakan komoditas ikan yang prospek untuk dikembangkan untuk skala rumah tangga sampai dengan skala industri, dengan cara menerapkan metode budi daya yang baik serta memperluas segmentasi pasar (Jatnika et al. 2014).

Budi daya ikan lele dapat dilakukan secara ekstensif dengan kolam tanah, kolam terpal sampai dengan intensif dengan metode bioflok dengan padat tebar yang tinggi (Windriani 2017). Budi daya pembesaran ikan lele secara sederhana dapat menggunakan kolam terpal sebagai media hidupnya. Kolam terpal mudah dibuat dan diperbanyak pada lahan yang tidak terlalu luas serta membutuhkan modal usaha yang tidak terlalu besar sampai dengan kemudahan dalam proses panen ikan (Hermawan 2013).

Beberapa orang memiliki anggapan bahwa usaha budi daya ikan lele mudah untuk dilakukan oleh setiap orang, karena secara teknis ikan lele merupakan ikan yang dapat hidup pada perairan dengan kualitas air yang kurang baik, lebih tahan penyakit dan dapat ditebar dengan kepadatan yang tinggi serta memiliki laju pertumbuhan yang cepat. Namun, pada kenyataannya tidak semua pelaku usaha budidaya ikan lele dapat menghasilkan keuntungan atau laba seperti yang diharapkan (Prihartono et al. 2010). Oleh karena itu, edukasi budi daya pembesaran ikan lele dengan secara sederhana pada kolam terpal berbasis teknologi probio_Fm kepada santri panti asuhan dapat dilakukan. Kegiatan pemberdayaan santri panti asuhan tersebut menggunakan kolam terpal sebagai media pembesaran ikan lele. Hal tersebut disebabkan kolam terpal merupakan media yang sederhana dan murah digunakan, serta dapat dibuat pada lahan yang tidak terlalu luas di panti asuhan. Selain penggunaan kolam terpal, terdapat aplikasi teknologi probio_Fm yang ditujukan untuk memperbaiki kualitas air kolam pada budidaya lele. Probio_Fm merupakan probiotik cair mengandung beberapa spesies bakteri asam laktat, yang merupakan hasil isolasi mikroba, diambil dari saluran pencernaan itik Kerinci (Manin et al. 2003; Manin 2010). Penambahan probiotik (probio_Fm) pada air kolam mampu meningkatkan kualitas air kolam sehingga dapat meningkatkan laju pertumbuhan ikan lele dan meningkatkan peluang hidup ikan lele yang dipelihara sampai dengan panen. Kandungan bakteri dalam probio_Fm mampu menekan pertumbuhan bakteri patogen, sehingga kandungan amoniak air kolam rendah dan kualitas air kolam tidak cepat menurun (Lisna 2015).

Edukasi budi daya pembesaran ikan lele kepada para santri panti asuhan Nurul Ikhsan merupakan salah satu bentuk pemberdayaan santri agar mengenal dan mampu mempraktikkan budidaya ikan lele dalam kolam terpal. Panti asuhan Nurul Ikhsan tersebut merupakan salah satu panti asuhan yang terletak di Kabupaten Bangka, Provinsi Kepulauan Bangka Belitung. Terdapat sejumlah 40 anak santri baik laki-laki dan perempuan tinggal di panti asuhan. Mereka mendapatkan pendidikan setingkat SMP maupun SMA serta mendapat pembinaan agama islam dari pengurus panti asuhan. Kegiatan pengabdian bertujuan untuk mengedukasi santri untuk dapat membudidayakan ikan lele dengan menggunakan kolam terpal yang disertai aplikasi probio_Fm. Budidaya ikan lele sangat potensi untuk dikembangkan, apabila sudah faham mengenai teori dan praktiknya. Harapannya setelah pemberdayaan, santri memiliki mengenal dan memiliki motivasi untuk dapat praktik budidaya ikan lele yang dapat menjadi bekal hidup dan dapat menjadi sumber pendapatan apabila sudah keluar lulus dari panti asuhan tersebut.

\section{METODE PELAKSANAAN KEGIATAN}

\section{Lokasi dan Partisipan Kegiatan}

Kegiatan edukasi dan pelatihan sebagai wujud pengabdian kepada masyarakat dilaksanakan di panti asuhan Nurul Ikhsan, Batu Rusa, Kecamatan Merawang, Kabupaten Bangka, Provinsi Kepulauan Bangka Belitung (Gambar 1). Tahapan persiapan sampai dengan pelaksanaan kegiatan membutuhkan waktu kurang lebih satu bulan (November 2018), sedangkan pelaksanan 


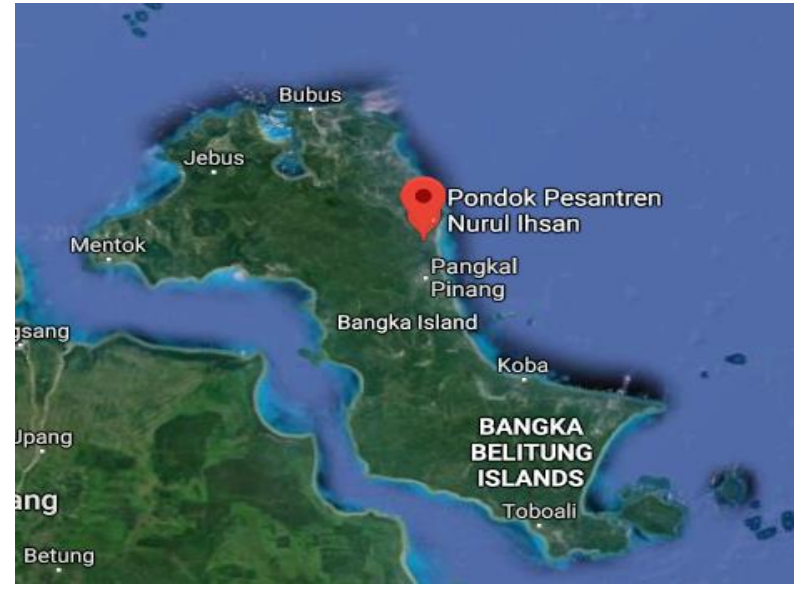

Gambar 1 Lokasi panti asuhan Nurul Ikhsan Kabupaten Bangka.

kegiatan pelatihan dan praktik di lapangan serta evaluasi kegiatan dilakukan pada bulan Desember 2018. Partisipan atau peserta kegiatan pelatihan pembesaran budidaya ikan lele ini merupakan santri perempuan dan laki-laki panti asuhan Nurul Ikhsan, Desa Batu Rusa. Jumlah peserta yang mengikuti kegiatan ini adalah 40 orang santri dengan didampingi oleh pengurus panti asuhan.

\section{Bahan dan Alat}

Pada saat kegiatan pemberdayaan, santri difasilitasi alat dan bahan yang digunakan untuk budidaya ikan lele dalam media kolam terpal. Bahan dan alat yang dibutuhkan untuk pelaksanaan kegiatan ini meliputi benih ikan lele (4-5 cm), terpal, pipa paralon, selang air, pakan ikan (pelet), probiotik (probio_Fm), serok, paku, palu dan baskom atau ember plastik. Alat dan bahan tersebut akan digunakan untuk media budidaya ikan lele pada kolam terpal ukuran 300 x 120 x $70 \mathrm{~cm}$ menurut Febriani \& Witoko (2018) yang dimodifikasi.

\section{Metode Pelaksanaan Kegiatan}

Pelaksanaan kegiatan pemberdayaan santri panti asuhan dilakukan melalui pemberian materi tentang budidaya ikan lele dengan metode ceramah dan diskusi, yang dilanjutkan dengan pendampingan praktik di lapangan. Tahapan pelaksanaan kegiatan pemberdayaan (Adi 2012) santri tersebut terbagi menjadi empat tahap yang dapat dijelaskan sebagai berikut:

\section{- Tahap persiapan}

Tahapan persiapan merupakan tahapan yang dilakukan sebelum pelaksaan kegiatan pelatihan. Persiapan yang dilakukan meliputi koordinasi dengan pengurus panti asuhan, menentukan waktu dan lokasi pembuatan kolam terpal sampai dengan mempersiapkan alat dan bahan yang diperlukan untuk pelaksanaan kegiatan tersebut (Febriani \& Witoko 2018).

\section{- Tahap pemberian materi}

Tahapan yang kedua pada kegiatan ini adalah pemberian materi secara langsung kepada peserta, yang dilakukan dengan metode ceramah dan diskusi. Materi yang diberikan pada saat pelatihan meliputi teori manajemen budidaya pembesaran ikan lele dengan metode kolam terpal dan manfaat probio_Fm.

\section{- Tahap praktik lapangan}

Kegiatan yang dilakukan setelah pemberian materi kepada partisipan adalah praktik di lapangan berdasarkan teori yang diberikan dengan didampingi oleh pengurus panti asuhan. Praktik lapangan tersebut meliputi pembuatan kolam terpal, cara tebar benih, cara pemberian pakan dan aplikasi probio_Fm pada air kolam terpal secara bertahap (10 $\mathrm{ml}$ per hari).

\section{- Tahap monitoring dan evaluasi pasca pelatihan}

Monitoring dilakukan untuk memantau proses pemeliharaan ikan setelah dilakukan edukasi maupun praktik pembuatan kolam, sedangkan evaluasi dilakukan melalui pembagian kuesioner kepada peserta atau santri, dalam rangka mengevaluasi kegiatan pemberdayaan yang telah dilakukan mulai dari persiapan sampai dengan selesainya kegiatan. Hasil evaluasi nantinya dapat mengukur tingkat motivasi santri serta menunjukkan perlu atau tidaknya keberlanjutan dari kegiatan yang telah dilakukan. Evaluasi tersebut dilakukan dengan cara pembagian kuesioner tertutup kepada 40 partisipan yang mengikuti rangkaian kegiatan yang telah dilakukan. Kuesioner tertutup tersebut berisikan 10 butir pertanyaan yang dibuat dengan menggunakan skala Likert (Joshi et al. 2015) dengan skala 1-5 yaitu sangat setuju (5), setuju (4), cukup setuju (3), kurang setuju (2) dan tidak setuju (1).

\section{Metode Pengumpulan, Pengolahan, dan Analisis Data}

Data yang dibutuhkan dalam kegiatan ini adalah data sekuder dan data primer. Data sekunder berupa data profil panti asuhan yang didapatkan secara langsung dari pengurus panti asuhan, sedangkan data primer diperoleh melalui dokumentasi secara langsung selama kegiatan 
pelatihan maupun praktik lapangan serta hasil kuesioner yang dibagikan kepada peserta pelatihan. Metode analisis data yang digunakan adalah analisis deskriptif kualitatif. Analisis deskriptif kualitatif yang dimaksud adalah menjelaskan atau menggambarkan hasil kegiatan yang dilakukan secara deskriptif dengan pendekatan induktif karena objek data yang digunakan bukan berupa angka (Sugiyono 2013). Analisis deskriptif kualitatif digunakan untuk menganalisis hasil kuesioner yang dibagikan kepada 40 peserta pelatihan dan hasil tersebut ditampilkan dalam bentuk tabel.

\section{HASIL DAN PEMBAHASAN}

Pemberdayaan masyarakat merupakan suatu konsep pembangunan dengan prinsip peoplecentered dan participatory. Pemberdayaan dalam hal ini berarti memicu masyarakat dengan segala keterbatasannya untuk mampu mandiri dalam mengatasi keterbatasannya, serta memiliki nilai budaya yang modern antara lain, tanggung jawab, kerja keras, hemat dan terbuka (Noor 2011). Kegiatan pemberdayaan masyarakat mengenai budi daya lele telah dilakukan di berbagai daerah (Putri et al. 2010; Darmansah et al. 2016; Hudaidah et al. 2017) dan hasilnya menunjukkan dampak yang positif karena kegiatan tersebut dapat menambah wawasan serta melatih keterampilan masyarakat. Hal yang tidak jauh berbeda diperoleh dari hasil kegiatan pengabdian yang dilakukan di panti asuhan Nurul Ikhsan, Batu Rusa.

\section{Tahap Persiapan}

Tahap persiapan merupakan tahap awal yang dilakukan sebelum kegiatan tersebut dilakukan. Persiapan kegiatan diawali dengan mendatangi Panti Asuhan Nurul Ikhsan yang terletak di desa Batu Rusa, dengan maksud meminta ijin kepada pimpinan Panti Asuhan yaitu Ibu Siti Hijir untuk melakukan kegiatan pelatihan budi daya pembesaran ikan lele. Penentuan waktu dan survei lokasi yang akan dijadikan tempat pembutan kolam terpal juga dilakukan pada tahap persiapan. Persiapan alat dan bahan dilakukan setelah mendapatkan ijin untuk melaksanakan kegiatan serta telah menentukan waktu pelaksanaan dan lokasi pembuatan kolam. Koordinasi dengan pengurus panti asuhan dilakukan dengan cara komunikasi secara langsung maupun tidak langsung.

\section{Tahap Pemberian Materi Budi Daya Pembesaran Ikan Lele Kolam Terpal}

Berdasarkan data profil panti asuhan, terdapat sejumlah 40 santri yang terdiri dari 28 anak perempuan dan 12 anak laki-laki. Santri tersebut merupakan pelajar setingkat SMP dan SMA. Mereka berasal dari daerah yang masih termasuk kedalam Provinsi Kepulauan Bangka Belitung. Kegiatan pemberian materi budidaya pembesaran ikan lele kolam terpal tersebut diikuti oleh 40 peserta yang terdiri dari 40 santri panti asuhan. Materi yang diberikan pada saat kegiatan berlangsung meliputi materi dasardasar budidaya ikan lele, manajemen kualitas air dengan aplikasi probio_Fm serta gambaran teknis pembuatan kolam terpal. Materi tersebut diberikan oleh tiga dosen pelaksana, selaku ketua dan anggota tim pengabdian (Gambar 2). Pemberian materi tersebut dilakukan melalui ceramah dan diskusi selama kegiatan berlangsung. Diskusi dilakukan setelah pemberian materi berlangsung dengan tujuan untuk menstimulasi para santri menjadi pribadi yang aktif di forum, selain itu tujuan lainnya adalah lebih memantapkan pemahaman para santri terhadap materi yang diberikan. Tidak terdapat kendala yang berarti saat kegiatan pemberian materi berlangsung. Namun, upaya menumbuhkan keingintahuan sampai dengan memotivasi santri untuk belajar budidaya ikan lele menjadi tantangan tersendiri pada saat pemberian materi pelatihan karena sebelumnya belum pernah mendapatkan edukasi maupun pelatihan mengenai budidaya lele. Hasil observasi pada saat pemberian materi, menunjukkan terdapat keseriusan para santri dalam mengikuti pelatihan yang ditandai dengan diskusi aktif santri dengan pemberi materi. Hal tersebut menunjukkan bahwa pemberian materi mengenai budidaya lele dengan kolam terpal, disertai aplikasi probio-Fm

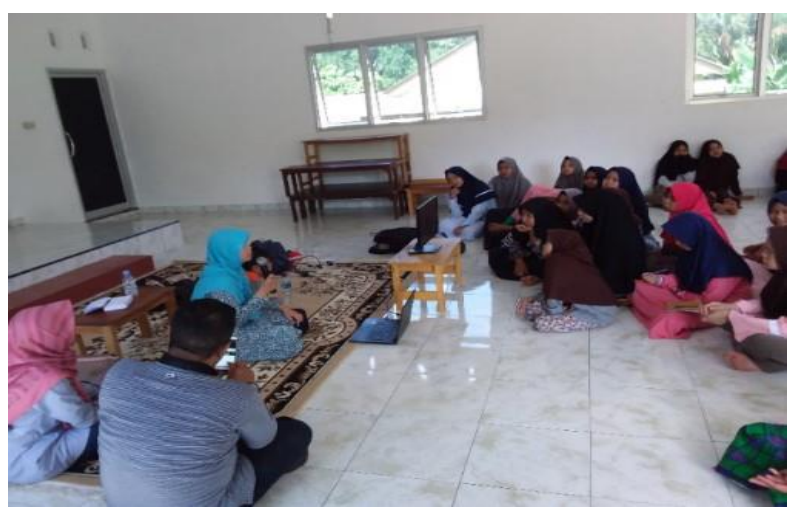

Gambar 2 Pelatihan mengenai budi daya ikan lele kolam terpal. 
berhasil disampaikan kepada santri. Berakhirnya kegiatan pemberian materi tersebut, diikuti dengan pemberian bantuan alat dan bahan untuk budidaya ikan lele , antara lain: benih ikan, terpal, pakan pelet dan probio_Fm (Gambar 3). Dampak positif yang diharapkan dari kegiatan ini adalah santri memiliki pengetahuan dan pemahaman mengenai dasar metode budidaya ikan lele secara konvensional dengan kolam terpal, yang nantinya dapat dipraktikkan sebagai bekal ketrampilan santri.

\section{Tahap Praktik Lapangan}

Pemberian materi mengenai budidaya ikan lele dengan kolam terpal dilanjutkan dengan pendampingan praktik secara langsung di lapangan. Hal tersebut bertujuan agar santri lebih faham mengenai teknis budidaya pembesaran ikan lele dalam kolam terpal. Pembuatan kolam lele terpal dengan ukuran $300 \times 120 \times 70 \mathrm{~cm}$ dilakukan oleh santri dengan dipandu oleh pengurus panti dan tim pengabdian (Gambar 4). Kerja bakti juga dilakukan untuk membersihkan lingkungan sekitar lokasi kolam terpal. Tahapan selanjutnya setelah pembuatan kolam terpal yaitu pengisian air ke dalam kolam terpal, serta memasukan bonggol pisang ke dalamnya (Gambar 5). Hal tersebut dilakukan supaya bahan kimia dalam terpal yang masih baru terserap oleh bonggol pisang. Pengurasan kolam dilakukan setelah tiga hari kemudian, yang dilanjutkan dengan pengisian air kembali dan penebaran benih ikan lele sebanyak 300 ekor (ukuran 5-7 $\mathrm{cm}$ ) serta pemberian probio_Fm $10 \mathrm{ml}$ pada air kolam setinggi $50 \mathrm{~cm}$. Pembagian jadwal piket untuk pengecekan kolam serta pemberian pakan dilakukan oleh santri panti asuhan yang diketuai oleh salah satu anak panti asuhan bernama Santo. Tujuannya adalah untuk melatih kemandirian serta tanggung jawab kepada para santri. Kegiatan pendampingan praktik pembuatan kolam budidaya ikan lele dengan kolam terpal berlangsung dengan baik dan lancar, karena santri dapat mempraktikkan secara langsung proses pembuatan kolam terpal setelah mendapatkan materi pelatihan budidaya ikan lele.

\section{Tahap Monitoring dan Evaluasi Kegiatan}

Monitoring dilakukan dengan tujuan memantau keberadaan ikan lele yang sedang dibudidayakan dalam kolam terpal, sedangkan evaluasi kegiatan dilakukan dengan cara sebar kuesioner terhadap santri setelah mengikuti kegiatan pelatihan maupun praktik di lapangan

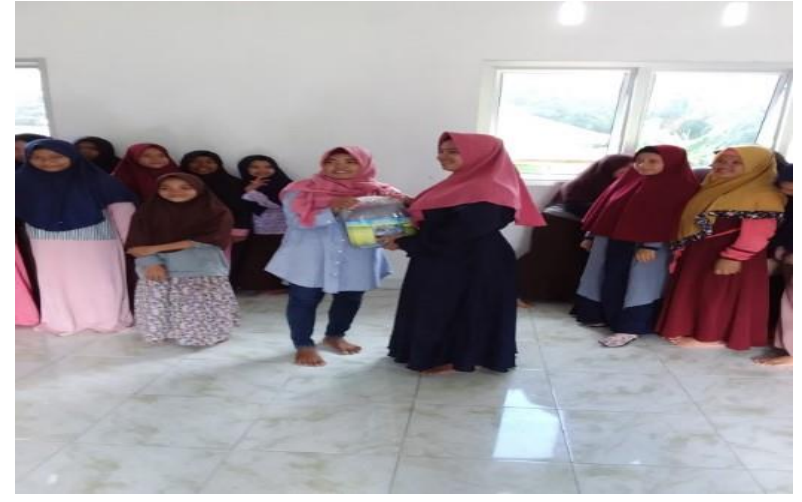

Gambar 3 Penyerahan fasilitas alat dan bahan budi daya ikan lele kepada santri.

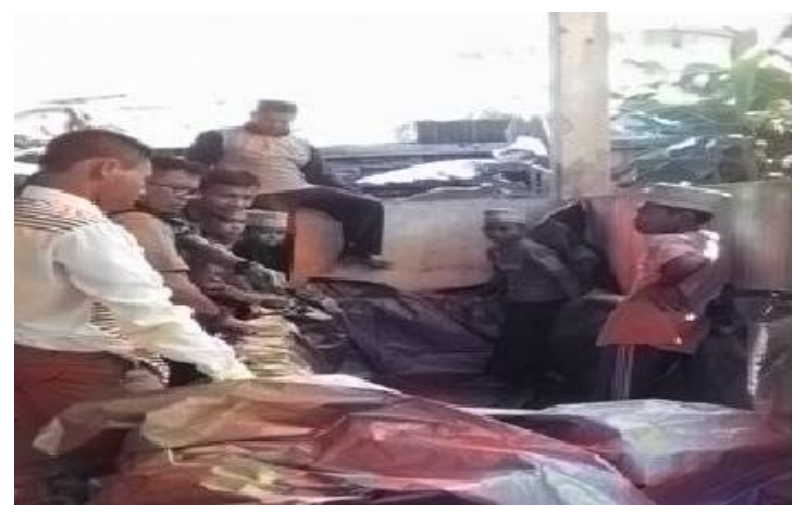

Gambar 4 Pembuatan kolam terpal.

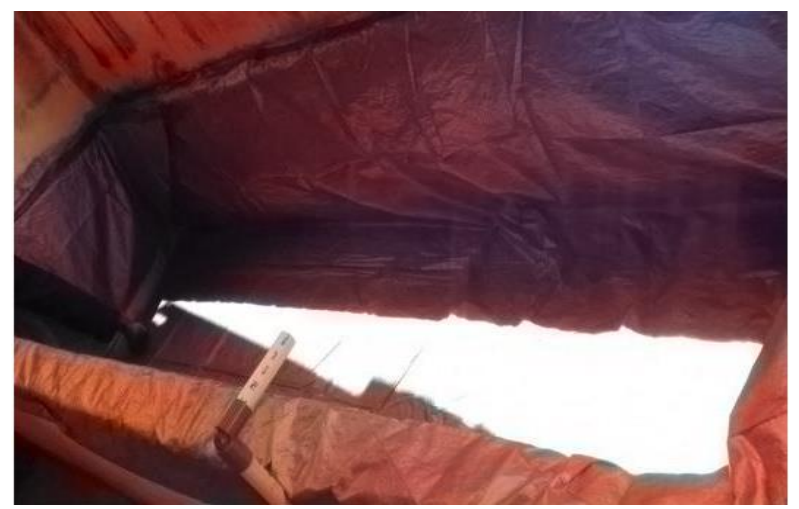

Gambar 5 Kolam terpal.

mengenai pembuatan kolam terpal untuk budidaya lele. Hasil kuesioner pada Tabel 1. menunjukkan bahwa sejumlah $92.9 \%$ dari 40 peserta yang hadir menyatakan setuju sampai dengan sangat setuju jika dikatakan mereka sangat termotivasi dan bersemangat dalam mengikuti kegiatan pelatihan. Untuk pertanyaan selanjutnya, $54,8 \%$ peserta menjawab setuju jika kegiatan tersebut sesuai dengan kebutuhan santri. Seorang santri juga mengutarakan secara langsung ketertarikannya terhadap materi budidaya ikan lele yang diberikan karena santri tersebut memiliki hobi untuk budidaya ikan. Terkait dengan sarana dan prasana, 52,4\% 
Tabel 1 Hasil kuesioner sebagai bahan evaluasi kegiatan

\begin{tabular}{|c|c|c|c|c|c|}
\hline \multirow{2}{*}{ Soal } & \multicolumn{5}{|c|}{ Persentase } \\
\hline & 1 & 2 & 3 & 4 & 5 \\
\hline $\begin{array}{l}\text { Peserta memiliki motivasi dan semangat yang tinggi dalam mengikuti } \\
\text { kegiatan }\end{array}$ & 2,4 & 0,0 & 4,8 & 54,8 & 38,1 \\
\hline Materi mudah dipahami dan jelas & 0,0 & 0,0 & 26,2 & 57,1 & 16,7 \\
\hline Praktik pembuatan kolam terpal dapat dipahami & 0,0 & 2,4 & 11,9 & 54,8 & 31 \\
\hline Keberlanjutan pelatihan diperlukan oleh peserta & 0,0 & 0,0 & 21,4 & 50,0 & 28,6 \\
\hline Pelatihan memberikan pengetahuan terhadap materi yang diberikan & 0,0 & 2,4 & 4,8 & 52,4 & 40,5 \\
\hline Materi sesuai dengan kebutuhan siswa & 0,0 & 2,4 & 16,7 & 54,8 & 26,2 \\
\hline $\begin{array}{l}\text { Pelatihan dan praktik yang dilakukan membekali peserta sehingga bisa } \\
\text { berkarya mandiri }\end{array}$ & 0,0 & 4,8 & 4,8 & 40,5 & 50 \\
\hline Pelaksanaan kegiatan berlangsung dengan baik dan lancar & 0,0 & 2,4 & 14,3 & 59,5 & 23,8 \\
\hline Metode pengabdian yang digunakan sudah tepat & 0,0 & 2,4 & 16,7 & 64,3 & 16,7 \\
\hline Sarana prasarana menunjang kegiatan pengabdian & 2,4 & 2,4 & 21,4 & 52,4 & 21,4 \\
\hline
\end{tabular}

peserta yang menyatakan setuju bahwa sarana dan prasana yang ada menunjang kegiatan yang dilaksanakan. Separuh peserta (50\%) juga menyatakan sangat setuju jika pelatihan dan edukasi dapat menumbuhkan ketrampilan santri sehingga bisa berkarya secara mandiri, selain itu sebagian dari mereka (50\%) juga menyatakan setuju untuk keberlanjutan dari kegiatan yang ada.

Monitoring dilakukan melalui komunikasi tidak langsung dengan media whatsapp untuk memantau kegiatan pemeliharaan ikan lele oleh santri sesuai dengan jadwal piket yang telah disepakati. Berdasarkan hasil monitoring, kendala yang dihadapi saat proses pemeliharaan ikan lele adalah pembagian jadwal pemberian makan ikan kurang terlaksana dengan baik karena santri panti asuhan memiliki rutinitas jadwal harian yang padat, sehingga pertumbuhan ikan lele yang dipelihara sangat lambat dan ukuran ikan lele yang diperoleh saat panen bulan ke empat tidak homogen. Hal tersebut bisa disebabkan karena kurangnya kontrol dalam pemeliharaan ikan lele. Hanya terdapat beberapa santri saja yang aktif mengecek keberadaan ikan lele setiap waktunya. Hal tersebut menunjukkan perlunya pendampingan pada saat proses pemeliharaan ikan lele oleh pengurus panti asuhan, selain itu perlu dilakukan komunikasi ulang dengan santri yang diberi tanggung jawab mengenai proses pemeliharaan ikan lele, agar ikan lele yang dipelihara dapat tumbuh dan berkembang dengan baik sampai dengan panen dilakukan. Secara umum, berdasarkan hasil evaluasi yang diperoleh dari kuesioner maupun observasi lapangan, kegiatan penyampaian materi budidaya ikan lele berlangsung dengan baik, namun pada saat praktik pemeliharaan ikan lele kurang berhasil karena hanya beberapa santri yang dapat memelihara ikan lele setiap harinya. Hal tersebut kemungkinan terdapat perbedaan minat serta jadwal santri yang padat dalam kesehariannya belajar di panti asuhan. Pendampingan secara intensif oleh pengurus panti asuhan maupun tim pengabdi dapat dilakukan ke depannya untuk keberhasilan proses budidaya ikan lele, selain itu edukasi mengenai analisis usaha budidaya lele dapat diberikan agar santri lebih termotivasi melihat peluang maupun keuntungan yang akan didapat ketika berhasil melakukan usaha budidaya ikan lele.

\section{SIMPULAN}

Simpulan yang dapat diperoleh dari kegiatan pemberdayaan santri panti asuhan Nurul Ikhsan yaitu kegiatan edukasi telah berhasil memberikan pengetahuan dan pemahaman mengenai metode budidaya lele kolam terpal berbasis probio_Fm, akan tetapi kurang berhasil dalam mempraktikkan pemeliharaan ikan lele pada saat proses budidaya. Keberlanjutan kegiatan dapat dilakukan melalui pendampingan secara intensif oleh tim pengabdi maupun pengurus panti asuhan untuk keberhasilan budidaya ikan lele sampai dengan panen, selain itu edukasi analisis usaha budidaya ikan lele dapat dilakukan untuk lebih memotivasi santri agar mampu melihat peluang maupun keuntungan dari usaha budidaya ikan lele kolam terpal.

\section{DAFTAR PUSTAKA}

Adi IR. 2012. Intervensi Komunitas dan Pengembangan Masyarakat Sebagai Upaya 
Pemberdayaan Masyarakat. Jakarta (ID): PT RajaGrafindo Persada.

Darmansah A, Sulistiono, Nugroho T, Supriyono E. 2016. Pemberdayaan Masyarakat melalui Pengembangan Budidaya Ikan Lele dumbo di Desa Balongan, Indramayu, Jawa Barat. Jurnal Ilmiah Pengabdian Kepada Masyarakat. Agrokreatif Jurnal Ilmiah Pengabdian kepada Masyarakat. 2(1): 8-16. https://doi.org/ 10.29244/agrokreatif.2.1.8-16

Febriani D, Witoko P. 2018. Bimbingan Teknis Pembuatan Kolam Terpal Untuk Budidaya Ikan di Desa Margajaya Kecamatan Metro Kibang Kabupaten Lampung Timur. Dalam: Prosiding Seminar Nasional Penerapan IPTEKS. Lampung (ID): Politeknik Negeri Lampung 08 Oktober 2018. Page: 82-89.

Hermawan H. 2013. Teknologi Budidaya Ikan Sistem Terpal pada KRPL. Jambi (ID): Balai Pengkajian Teknologi Pertanian (BPTP).

Hudaidah S, Wardiyanto, Hasani Q, Yusup MW. 2017. Pemberdayaan Masyarakat Melalui Pengembangan Budidaya Ikan Lele dumbo Teknologi Bioflok di Kelurahan Pinang Jaya, Bandar Lampung, Lampung. Sakai Sambayan Jurnal Pengabdian kepada Masyarakat. 1(1): 17-22.

Jatnika D, Sumanantadinata K, Pandjaitan NH. 2014. Pengembangan Usaha Budi daya Ikan Lele (Clarias sp.) di Lahan Kering di Kabupaten Gunungkidul, Provinsi Daerah Istimewa Yogyakarta. Manajemen IKM. 9(1): 96-105. https://doi.org/10.29244/mikm.9.1. 96-105

Joshi A, Kale S, Chandel S, Pal DK. 2015. Likert Scale: Explored and Explained. British Journal of Applied Science \& Technology. 7(4): 396403. https://doi.org/10.9734/BJAST/2015/ 14975

Lisna I. 2015. Potensi mikroba probiotik_FM dalam meningkatkan kualitas air kolam dan laju pertumbuhan benih ikan lele dumbo dumbo (Clarias gariepinus). Jurnal Penelitian Universitas Jambi: Seri Sains.17(2): 18-25.

Manin F, Hendalia E, Yatno, Kompiang IK. 2003. Potensi Saluran Pencernaan Itik Lokal Kerinci
Sebagai Sumber Probiotik dan Implikasinya Terhadap Produktivitas Ternak dan Penanggulangan kasus Salmonellosis. Laporan Penelitian Hibah Bersaing X Tahun Kedua. Fakultas Peternakan Universitas Jambi.

Manin F. 2010. Potensi Lactobacillus acidophilus dan Lactobacillus fermentum dari saluran pencernaan ayam buras asal lahan gambut sebagai probiotik. Jurnal IImu-ilmu Peternakan. 13(05): 221-228.

Noor M. 2011. Pemberdayaan Masyarakat. Jurnal Ilmiah CIVIS. 1(2): 87-99.

Prihartono, E, Juansyah R, Usnie A. 2010. Mengatasi Permasalahan Budidaya Lele dumbo Dumbo. Jakarta (ID): Penerbit PT Penebar Swadaya.

Putri HM, Asnawi, Hikmayani Y. 2010. Pemanfaatan Lahan Pekarangan sebagai Bentuk Pemberdayaan Sosial Ekonomi Masyarakat melalui Usaha Budidaya Lele dumbo (Studi Kasus di Desa Salamredjo Kecamatan Sentoloyo, Kulon Progo, DIY). Jurnal Sosial Ekonomi Kelautan dan Perikanan. 5(10):159-167. https://doi.org/10.15578/ jsekp.v5i2.5798

Saparinto C. 2013. Budidaya Ikan di Kolam Terpal. Jakarta(ID): Penerbit Swadaya.

Sugiyono. 2013. Metode Penelitian Pendidikan Pendekatan Kuantitatif, Kualitatif, dan R\&D. Bandung (ID): Alfabeta.

Triyanti R, Shafitri N. 2012. Kajian Pemasaran Ikan Lele dumbo (Clarias Sp) dalam Mendukung Industri Perikanan Budidaya (Studi Kasus di Kabupaten Boyolali, Jawa Tengah). Jurnal Sosial Ekonomi Kelautan dan Perikanan. 7(2): 177-191. https://doi.org/ 10.15578/jsekp.v7i2.5684

Wardiningsih S. 2014. Teknik Pembenihan Ikan. In: Prasarana dan Sarana Pembenihan Ikan. Jakarta (ID): Universitas Terbuka. Page 1-53.

Windriani U. 2017. Buku Saku Budi daya Ikan Lele Sistem Bioflok. Jakarta (ID): Direktorat Produksi dan Usaha Budidaya. Kementrian Kelautan dan Perikanan. Page 1-38. 